\title{
ANALISIS E-TRUST, E-WOM, DAN E-SERVICE QUALITY DALAM KEPUTUSAN PEMBELIAN ONLINE
}

\author{
Emeralda, Jeni Wulandari, Diang Adistya \\ Jurusan Ilmu Administrasi Bisnis, Fakultas Ilmu Sosial dan Politik, Universitas Lampung \\ * emeralda.galuhpasha@gmail.com
}

\begin{abstract}
This study aims to determine the effect of e-trust, e-wom and e-service quality on online purchasing decisions for Tokopedia users in Bandar Lampung. This research conducted with an explanatory research approach. The sample of this research is Tokopedia users who have made transactions more than once in appllication, with total 100 respondents using accidental sampling technique. Data analysis was performed by descriptive and multiple linear analysis. The results showed that e-trust, e-wom, and e-service quality partially and simultaneously have a positive and significant effect on online purchasing decisions. The online purchasing decision factor in this study is mostly influenced by e-wom. Need to support improvements in aspects of Tokopedia's ability to provide trust, ease in sharing their shopping experience in applications, and efficiency in fulfillment costumer needs.
\end{abstract}

Keywords: e-trust, e-wom, e-service quality, online purchasing decisions

\begin{abstract}
ABSTRAK
Penelitian ini dilakukan untuk mengetahui pengaruh $e$-trust, $e$-wom, dan e-service quality terhadap keputusan pembelian online pada pengguna Tokopedia di Bandar Lampung. Penelitian ini merupakan penelitian kuantitatif dengan pendekatan explanatory research. Sampel penelitian ini adalah pengguna aplikasi Tokopedia yang telah melakukan transaksi lebih dari satu kali pada aplikasi, dengan jumlah responden sebanyak 100 orang, yang dilakukan dengan teknik accidental sampling. Analisis data dilakukan dengan menggunakan analisis deskriptif dan analisis linear berganda. Hasil penelitian ini menunjukkan bahwa e-trust, e-wom dan e-service quality secara parsial dan simultan berpengaruh positif dan signifikan terhadap keputusan pembelian online. Perlu dukungan peningkatan pada aspek kemampuan Tokopedia dalam memberikan kepercayaan (ability), kemudahan dalam membagikan pengalaman berbelanjanya menggunakan aplikasi Tokopedia (expressive positive feeling), dan efisiensi dalam memenuhi kebutuhan pelanggan.
\end{abstract}

Kata kunci: e-trust, e-wom, e-service quality, keputusan pembelian online. 


\section{PENDAHULUAN}

Sejak diperkenalkan pada tahun 1969 di Amerika Serikat, internet mengalami perkembangan yang luar biasa, apalagi dengan diperkenalkannya teknologi World Wide Web (WWW), semakin menambah sempurnanya teknologi tersebut (McLeod \& Schell, 2004:64). Internet pun membawa dampak perubahan yang menciptakan pandangan baru dalam berbisnis, yakni berupa pemasaran digital.

Pemasaran digital adalah kegiatan promosi dan pencarian pasar melalui media digital secara online dengan memanfaatkan berbagai sarana, misalnya jejaring sosial. Dunia online mampu menghubungkan semua orang dari seluruh dunia. Digital marketing memudahkan pebisnis memantau dan menyediakan segala kebutuhan dan keinginan calon konsumen. Calon konsumen juga bisa mencari dan mendapatkan informasi produk hanya dengan cara menjelajah dunia maya sehingga mempermudah proses pencariannya (Purwana, et al., 2017:2).

Berkembangnya digital marketing menyebabkan meningkatnya nilai transaksi ecommerce atau perdagangan elektronik. E-commerce adalah transaksi bisnis yang terjadi dalam jaringan elektronik seperti internet. Siapapun yang mempunyai perangkat yang mampu mengakses jaringan internet dapat mengikuti kegiatan e-commerce (Varmaat, 2007:83).

Banyak aplikasi e-commerce yang ada di Indonesia, tetapi Tokopedia menjadi marketplace dengan pengguna tertinggi di Indonesia (Jayani \& Fitra, 2019). Tokopedia memiliki misi pemerataan ekonomi secara digital. Sejak didirikan pada 17 Agustus tahun 2009, Tokopedia telah bertransformasi menjadi sebuah unicorn yang berpengaruh tidak hanya di Indonesia, tetapi juga di Asia Tenggara (Evandio, 2021).

Namun, sejalan dengan semakin tingginya transaksi online, maka semakin tinggi pula kejahatan online, kasus penipuan online, pemerasan, prostitusi online, bahkan kasus pencucian uang \& korupsi yang terjadi di dunia online. Berdasarkan tingginya kasus penipuan online, maka e-commerce berlomba-lomba untuk menyediakan layanan yang aman bagi konsumennya, agar konsumen percaya dalam melakukan transaksinya. Dalam konteks elektronik, kepercayaan ini diistilahkan dengan e-trust. E-trust merupakan suatu harapan konsumen bahwa penyedia barang atau jasa bisa dipercaya atau diandalkan dalam memenuhi janjinya (Siagian \& Cahyono, 2014:57).

Secara garis besar, e-trust atau kepercayaan konsumen dapat dibangun dengan melihat ulasan positif yang diberikan konsumen pasca pembelian yang terdapat dalam aplikasi e-commerce. Maka dari itu, ulasan sangat penting dan dibutuhkan oleh para penyedia barang di e-commerce agar barang yang ditawarkan laku terjual. Selain melihat ulasan yang positif, e-trust dapat dibangun dengan memastikan data diri konsumen tersimpan dengan aman, menampilkan lokasi toko yang jelas, dan dukungan pengiriman. Ketersediaan informasi tersebut, dapat mendorong konsumen untuk melakukan pembelian melalui e-commerce (Mahkota, et al., 2014).

Review positif secara tidak langsung juga dapat menjadi salah satu bentuk promosi. Semakin banyaknya e-commerce bermunculan, maka penyedia layanan harus bersaing mencari pelanggannya, dan menjaga ketat peraturan agar dapat dipercaya sebagai $e$ commerce yang baik. Sehingga selain melalui iklan, review dari pelanggan yang dapat dilihat pada ulasan produk, dapat menjadi informasi positif yang tersebar dengan baik 
dari mulut ke mulut. Dalam konteks elektronik, hal ini disebut e-wom. E-wom adalah pernyataan positif atau negatif yang dilakukan oleh konsumen potensial, aktual, maupun mantan konsumen tentang produk atau perusahaan melalui internet (Paludi, 2016:23).

Selain e-trust dan e-wom, e-service quality juga berpengaruh terhadap keputusan pembelian online. E-Service quality adalah sebuah penilaian apa yang konsumen terima dengan apa yang konsumen harapkan saling bersesuaian atau berlawanan. Oleh karena itu, kualitas pelayanan online merupakan suatu hal penting yang harus diperhatikan oleh setiap penjual yang terdapat di e-commerce (Rozi, 2017).

Setelah konsumen percaya kepada suatu e-commerce melalui rangsangan dari e-wom, dan merasa puas dengan fasilitas pelayanannya, maka konsumen akan memutuskan untuk melakukan pembelian. Keputusan pembelian online merupakan serangkaian proses yang berawal dari konsumen mengenal masalahnya, mencari informasi tentang produk atau merek tertentu dan mengevaluasi produk atau merek tersebut seberapa baik masingmasing alternatif tersebut dapat memecahkan masalahnya, yang kemudian serangkaian proses tersebut mengarah kepada keputusan pembelian online (Tjiptono, 2014:21).

Penelitian yang berhubungan dengan penggunaan e-commerce, menjadi bagian yang cukup penting dalam kajian perilaku konsumen saat ini. Para pemasar membutuhkan informasi yang akurat, tepat waktu dan handal mengenai para konsumennya dan keterampilan khusus untuk menganalisis dan menginterpretasikan informasi tersebut guna menunjang perancangan strategi pemasaran yang efektif dan efisien (Suwarman \& Tjiptono, 2018:75). Perilaku konsumen menggambarkan cara individu mengambil keputusan untuk memanfaatkan sumber daya mereka yang tersedia (waktu, uang, usaha) dalam mencari, membeli, menggunakan, mengevaluasi dan menghabiskan produk dan jasa yang mereka harapkan akan memuaskan kebutuhan mereka (Schiffman \& Kanuk, 2010:23).

Proses tersebut tergambar dalam model perilaku konsumen (Kotler \& Amstrong, 2012), dimana terdapat beberapa komponen, yakni rangsangan pemasaran (produk ,harga, promosi dan distribusi), rangsangan lain-lain (ekonomi, teknologi, politik dan budaya), dan karakteristik pembeli (budaya, sosial, personal dan psikologi). Mengacu pada model perilaku tersebut, penelitian ini berfokus pada rangsangan pemasaran berupa $e$-wom dan e-service quality, serta karakteristik pembeli berupa e-trust sebagai gambaran terhadap variabel yang mempengaruhi keputusan pembelian online menggunakan aplikasi Tokopedia.

E-trust merupakan sebuah kepercayaan yang dimiliki konsumen untuk membeli melalui internet. Transaksi online yang dimaksud adalah suatu kegiatan dimana proses pencarian informasi, transfer informasi, dan pembelian produk terjadi secara online (Pavlou, 2003:17). E-trust pada penelitian ini dapat diukur dalam tiga dimensi yakni, ketulusan (benevolence), kemampuan (ability), integritas (integrity). Terdapat beberapa penelitian sebelumnya yang menunjukkan keterkaitan e-trust dengan keputusan pembelian online, sebagaimana penelitian yang dilakukan oleh Mauludiyahwati (2017); Setyowati \& Suryoko (2020); Kartika \& Garnasih (2018); Nugraha, et al. (2019) bahwa etrust berpengaruh positif terhadap keputusan pembelian online. Berdasarkan hasil studi tersebut, maka dapat disusun hipotesis pertama:

H1: E-trust berpengaruh signifikan terhadap keputusan pembelian online pada pengguna Tokopedia. 
Sementara itu, electronic word of mouth (e-wom) dapat diartikan sebagai "pernyataan negatif atau positif yang dibuat oleh konsumen aktual, potential atau konsumen sebelumnya mengenai produk atau perusahaan dimana informasi ini tersedia bagi orangorang ataupun institusi melalui via media internet" (Paludi, 2016:23). E-wom pada penelitian ini dapat diukur dalam tiga dimensi yaitu, kepedulian terhadap orang lain (concern for others), mengekspresikan perasaan positif atau negatif (expressing positive feelings), membantu perusahaan (helping the company). Terdapat beberapa penelitian sebelumnya yang menujukkan keterkaitan e-wom dengan keputusan pembelian online, sebagaimana penelitian yang dilakukan oleh Yunitasari (2018); Oktaviani (2020); Sindunata \& Wahyudi (2018); Perera, et al. (2019); Tjhin \& Aini (2019), Bahwa e-wom berpengaruh positif terhadap keputusan pembelian online. Berdasarkan hasil studi tersebut maka dapat disusun hipotesis kedua:

H2: E-wom berpengaruh signifikan terhadap keputusan pembelian online pada pengguna Tokopedia.

E-service quality atau yang juga dikenal sebagai e-ServQual merupakan versi baru dari service quality (ServQual). E-ServQual dikembangkan untuk mengevaluasi suatu pelayanan yang diberikan pada jaringan Internet. E-service quality didefinisikan sebagai perluasan dari kemampuan suatu situs untuk memfasilitasi kegiatan belanja, pembelian, dan distribusi secara efektif dan efisien (Chase, et al., 2006:4). E-service quality pada penelitian ini dapat diukur dalam 4 dimensi yakni, efisien (efficiency), pemenuhan (fulfilment), ketersediaan system (system availability), privasi (privacy). Terdapat beberapa penelitian sebelumnya yang menunjukkan keterkaitan e-service quality dengan keputusan pembelian online, sebagaimana penelitian yang dilakukan oleh Fakhrur (2017); Gupron (2020); Oktari (2018); Amanah, et al. (2017); Mahfud \& Soltes (2016), bahwa e-service quality berpengaruh positif terhadap keputusan pembelian online. Berdasarkan hasil studi tersebut maka dapat disusun hipotesis ketiga:

H3: E-service quality berpengaruh signifikan terhadap keputusan pembelian online pada pengguna Tokopedia.

Keputusan pembelian merupakan serangkaian proses yang berawal dari konsumen mengenal masalahnya, mencari informasi tentang produk atau merek tertentu, dan mengevaluasi produk atau merek tersebut, seberapa baik masing-masing alternatif dapat memecahkan masalahnya, yang kemudian serangkaian proses tersebut mengarah kepada keputusan pembelian (Tjiptono, 2014:21). Kotler \& Amstrong (2016:188) menjelaskan keputusan pembelian memiliki 6 dimensi, yaitu: pilihan produk, pilihan merek, pilihan penyalur, waktu pembelian, jumlah pembelian, dan metode pembayaran. Hasil penelitian oleh Ansyah (2019); Sindunata \& Wahyudi (2018); Kalia (2016), menunjukkan bahwa kepercayaan (trust), e-wom, dan e-servqual berpengaruh positif dan signifikan terhadap keputusan pembelian online. Berdasarkan hasil studi tersebut maka dapat dibangun hipotesis ke empat:

H4: E-trust, e-wom, dan e-service quality secara simultan berpengaruh signifikan dan 
postif terhadap keputusan pembelian online pada pengguna Tokopedia.

\section{METODE PENELITIAN}

Penelitian ini merupakan penelitian kuantitatif dengan menggunakan pendekatan explanatory research. Teknik pengumpulan data dilakukan dengan menggunakan kuesioner dan menggunakan skala pengukuran likert, disebarkan secara online dengan Google Forms melalui aplikasi Whatsapp dan Instagram. Analisis data dilakukan dalam beberapa tahapan, yakni analisis statistik deskriptif, uji asumsi klasik, analisis regresi linear berganda, uji t, uji F, dan koefisien determinasi.

Adapun populasi yang diambil dalam penelitian ini adalah para pengguna Tokopedia di Bandar Lampung, dan pernah melakukan transaksi di Tokopedia minimal satu kali transaksi. Pada penelitian ini tidak diketahui jumlah populasinya, maka menurut Sugiyono, (2017:148) bila jumlah populasi dalam penelitian ini tidak diketahui jumlahnya, maka perhitungan jumlah sampel menggunakan rumus sebagai berikut.

$$
\mathrm{n}=\frac{N}{1+N(e)^{2}}
$$

Keterangan:

$$
\begin{array}{ll}
\mathrm{N} & =\text { Ukuran sampel } \\
\mathrm{n} & =\text { Jumlah Populasi } \\
\mathrm{e} & =\text { Posisi yang ditetapkan }(5 \%)
\end{array}
$$

Berdasarkan rumus tersebut maka jumlah sampel yang akan diteliti yaitu:

$$
\begin{aligned}
& \mathrm{n}=\frac{133}{1+1,33(0,05)^{2}} \\
& \mathrm{n}=\frac{133}{1+133(0,0025)^{2}} \\
& \mathrm{n}=\frac{133}{1,3325} \\
& \mathrm{n}=99,81
\end{aligned}
$$

Sehingga sampel yang digunakan dalam penelitian ini berjumlah 99,81 atau dibulatkan menjadi 100 responden.

\section{HASIL PENELITIAN}

Analisis Statistik Deskriptif

Berdasarkan hasil analisis deskriptif pada penelitian ini, diketahui mayoritas responden adalah wanita (65\%), dengan rentang usia terbesar diatas 29 tahun (40\%). Sifat 
wanita yang lebih impulsif dibanding dengan pria dalam berbelanja menjadi alasan mengapa wanita lebih banyak menggunakan aplikasi belanja online seperti Tokopedia (Amalia, 2019). Pendapatan rata-rata terbanyak berada dalam rentang Rp. 500.000 sampai Rp. 5.000.000. Kebanyakan responden (67\%) juga telah menggunakan Tokopedia selama lebih dari 1 tahun dengan intensitas penggunaan selama seminggu sekali (45\%).

Pada variabel e-trust rata-rata responden memberikan penilaian 4.11, artinya e-trust masuk dalam kategori penilaian "tinggi", sehingga hal ini dapat diketahui bahwa responden memiliki kepercayaan yang tinggi terhadap keputusan pembelian. Dimensi item variabel yang berada di atas nilai rata (4.11) meliputi ketulusan dan integritas. Dimensi kemampuan (ability) memiliki nilai rata rata dibawah 4.11, hal inilah yang dirasakan oleh pelanggan Tokopedia, masih ada yang belum terpenuhi oleh Tokopedia dalam memenuhi kepuasan pelanggannya. Tokopedia dirasakan kurang mampu dalam menyediakan barang yang berkualitas. Artinya Tokopedia harus lebih meningkatkan sortasi kualitas produk yang ada di Tokopedia.

Pada variabel e-wom, rata-rata jawaban responden adalah 3.66, artinya persepsi konsumen masuk dalam kategori "tinggi". Hal ini dapat diketahui bahwa responden memiliki persepsi yang tinggi terhadap variabel E-wom. Dimensi item variabel yang berada di atas rata-rata 3.66 meliputi Concern for others dan Helping the company. Responden merasakan kerpedulian Tokopedia memberikan fasilitas untuk berinteraksi langsung dengan penjual, Tokopedia memberikan fasilitas kolom diskusi untuk para konsumennya. UKM yang ada juga merasa terbantu dalam memasarkan produknya, sehingga terciptalah proses jual beli yang aman dan mudah. Untuk dimensi Expressing positive feelings, mendapatkan nilai rata-rata dibawah 3.66, artinya pada dimensi ini dapat diketahui bahwa pelanggan Tokopedia kurang merasakan kemudahan dalam membagikan pengalaman berbelanjanya menggunakan aplikasi Tokopedia.

Pada variabel e-service quality memiliki rata-rata nilai sebesar 3.77, artinya persepsi konsumen masuk dalam kategori "tinggi". Hal tersebut dapat diketahui bahwa responden memiliki persepsi konsumen yang tinggi terhadap pelayanan Tokopedia. Item yang berada di atas rata-rata (3.77) meliputi pemenuhan (fulfillment), ketersediaan system (system availability), dan privasi (privacy). Dalam hal ini Tokopedia dapat memberikan kepuasan atas pemenuhan fasilitas yang mereka punya, fasilitas yang dimiliki Tokopedia dapat diandalkan, dan berjalan tanpa masalah. System keamanan yang baik dalam bertransaksi, Tokopedia juga memastikan data pribadi yang dimiliki konsumen tidak akan disebarluaskan, terbukti terdapat pilihan anonim saat kita ingin meninggalkan ulasan pada suatu produk. Item pada dimensi efisiensi berada dibawah nilai rata-rata (3.77), namun nilai nya tidak terlalu jauh, yang dirasakan oleh konsumen Tokopedia adalah kurang dalam memenuhi kemudahan dalam menemukan produk yang diinginkan konsumen, beberapa layanan Tokopedia juga harus membutuhkan waktu untuk mengkonfirmasi pembayaran, dan juga ada metode pembayaran yang harus dilakukan secara manual untuk mengkonfirmasi pembayaran.

Distribusi jawaban responden pada variabel keputusan pembelian online memiliki nilai rata-rata 4, artinya keputusan pembelian masuk dalam katageri "tinggi". Hal tersebut dapat diketahui bahwa responden memiliki kecendrungan tinggi untuk melakukan keputusan pembelian online di Tokopedia. Item yang berada di atas nilai rata-rata (4) meliputi pilihan penyalur, waktu pembelian, jumlah pembelian, dan metode pembayaran. 
Hal ini dirasakan sangat membantu oleh pengguna Tokopedia, pengguna Tokopedia diberikan beberapa pilihan produk dari berbagai macam merchat yang tersedia di Tokopedia, sehingga memudahkan penggunanya untuk memilih produk apa yang cocok. Tokopedia juga memiliki banyak metode pembayaran, pengguna Tokopedia hanya perlu memilih metode pembayaran mana yang dia inginkan.

Uji Asumsi Klasik

Uji Normalitas

Uji normalitas digunakan untuk menguji apakah dalam model regresi, variabel variabel memiliki distribusi normal atau tidak. Model regresi yang baik adalah memiliki distribusi memiliki data normal atau tidak. Jika tingkat signifikan probabilitas $>0,05$ maka data penelitian berdistribusi normal. Pada penelitian ini, terdapat bahwa nilai asymp sig sebesar 0,133. Maka dapat disimpulkan bahwa penelitian ini terdistribusi normal

\section{Uji Heteroskedastisitas}

Uji Heteroskedastisitas adalah pengujian yang dilakukan untuk mengatahui apakah model regresi valid atau tidak sebagai alat peramalan. Hasil penelitian ini menunjukkan titik-titik yang terdapat dalam scatterplot tidak membentuk pola terentu, maka dapat disimpulkan penelitian ini tidak terdapat heteroskedastisitas.

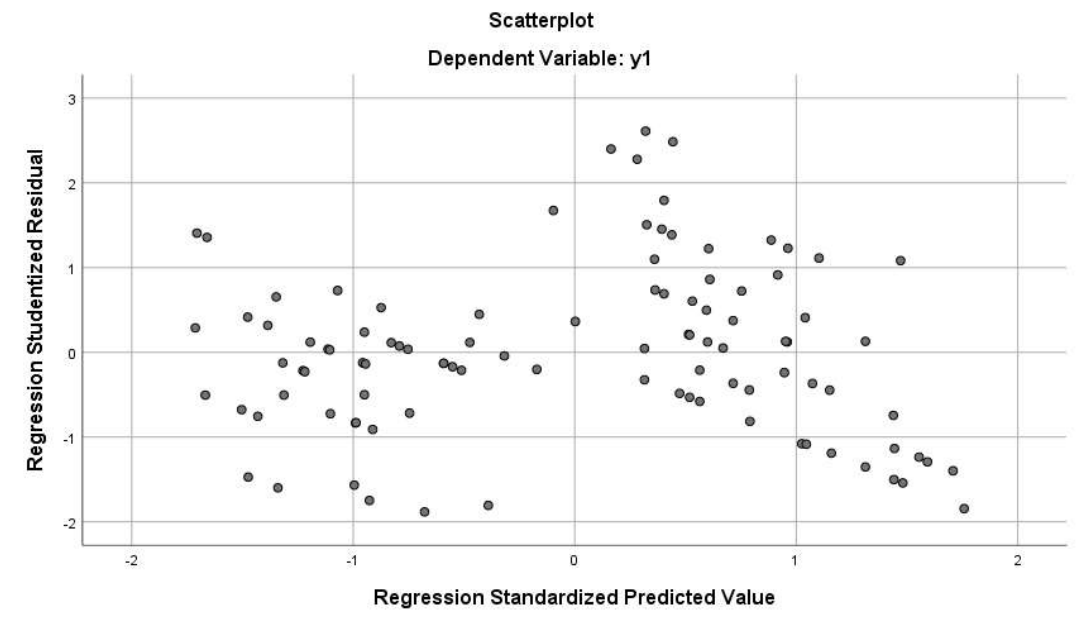

Gambar 1. Hasil Uji Heteroskedastisitas

\section{Uji Multikolonieritas}

Uji Multikolinearitas bertujuan untuk menguji apakah model regresi ditemukan adanya korelasi antar variabel bebas. Hasil penenelitian ini menunjukkan bahwa variabel dalam penelitian ini memiliki nilai VIF masing-masing <10 yaitu x1 $(1,933) \times 2(1,865)$ dan x3 $(1,523)$ dan nilai tolerance masing-maisng variabel $>0,10$. yaitu $x 1(0,517) \times 2(0,536)$ dan x3 $(1,523)$. Maka dari itu dapat disimpulkan model regresi pada penelitian ini adalah baik, karena tidak terjadi korelasi diantara variabel bebas atau variabel independen.

Tabel 1. Hasil Uji Multikolinieritas

\section{Coefficients ${ }^{\mathrm{a}}$}

\begin{tabular}{l|l} 
& \\
$\mathrm{t}$ & $\mathrm{Sig}$
\end{tabular}

Collinearity

Statistics 


\begin{tabular}{|c|c|c|c|c|c|c|c|c|}
\hline & & B & Std. Error & Beta & & & Tolerance & VIF \\
\hline \multirow[t]{4}{*}{1} & (Constant) & 18,557 & 3,372 & & 5,504 & ,000 & & \\
\hline & $\mathrm{x} 1$ & ,329 & 118 & ,276 & 2,793 & ,006 & ,517 & 1,933 \\
\hline & $x 2$ & ,449 & 120 & ,364 & 3,751 & ,000 & ,536 & 1,865 \\
\hline & $x 3$ & 217 & ,096 & 199 & 2,266 & ,026 & 657 & 1,523 \\
\hline
\end{tabular}

a. Dependent Variable: y1

Analisis Regresi Linear Berganda

Analisis regresi linear berganda adalah analisis yang digunakan untuk meramalkan keadaan (naik turunnya) variabel dependen, jika dua atau lebih variabel independen sebagai faktor prediktor dimanipulasi (dinaik turunkan nilainya).

Tabel 2. Hasil analisis regresi linear berganda

Coefficients ${ }^{a}$

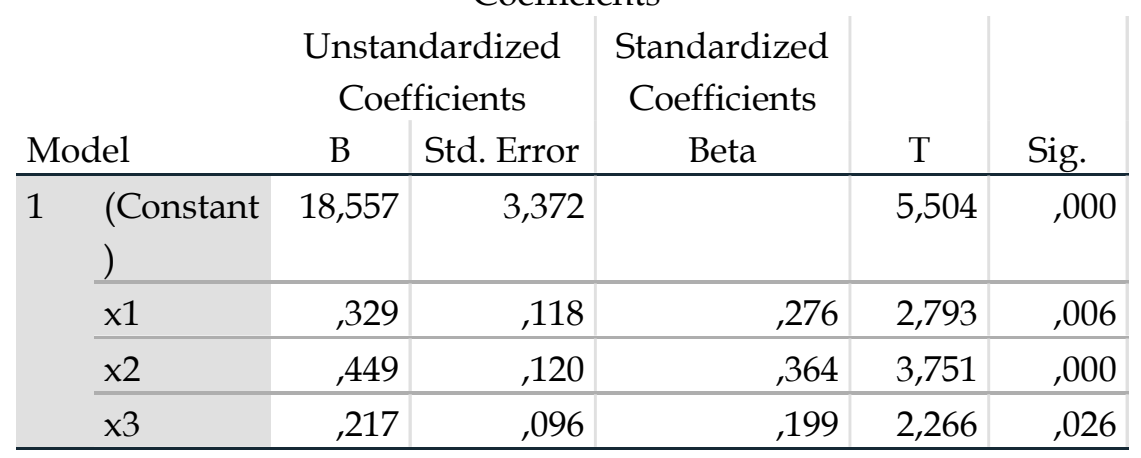

a. Dependent Variable: y1

Berdasarkan tabel 2 hasil perhitungan regresi linear berganda, dapat dilihat bahwa nilai constant sebesar 18.557, nilai e-trust (X1) sebesar 0,329, nilai e-wom (X2) sebesar 0,449, dan nilai $e$-service quality (X3) sebesar 0.217. Berdasarkan nilai-nilai tersebut pada masingmasing variabel, maka untuk mengetahui e-trust, e-wom, dan e-service quality terhadap keputusan pembelian online melalui aplikasi Tokopedia dapat dilihat pada persamaan regresi berikut ini:

$$
\begin{gathered}
Y=\alpha+\beta_{1} X 1+\beta_{2} X 2+\beta_{3} X 3+e \\
Y=18.557+0.0329+0.449+0.217+\mathrm{e}
\end{gathered}
$$

Berdasarkan persamaan regresi tersebut dapat dijelaskan hasil regresi linear berganda sebagai berikut: Persamaan regresi dalam penelitian ini memiliki konstanta sebesar 18,557 yang berarti bahwa jika variabel independen e-trust (X1), e-wom (X2), eservice quality $(X 3)$ memiliki nilai 0 , maka nilai variabel dependen keputusan pembelian online (Y) adalah sebesar 18,557. Koefisien regresi linear berganda variabel e-trust (X1) bernilai positif sebesar 0,329 . Hal ini menunjukkan bahwa terjadi pengaruh yang positif antara variabel e-trust terhadap keputusan pembelian online. Artinya setiap terjadi kenaikkan nilai 1 dari variabel e-trust, maka keputusan pembelian online pengguna Tokopedia akan mengalami peningkatan sebesar 0,329.

Koefisien regresi linear berganda variabel e-wom (X2) bernilai positif sebesar 0,449. Hal ini menunjukkan bahwa terjadi pengaruh yang positif antara variabel antara $e$-wom 
terhadap keputusan pembelian online. Artinya setiap terjadi kenaikan nilai 1 dari variabel e-wom, maka keputusan pembelian online pengguna Tokopedia akan mengalami peningkatan sebesar 0,449. Koefisien regresi linear berganda variabel e-service quality (X3) bernilai positif sebesar 0,217 . Hal ini menunjukkan bahwa terjadi pengaruh yang positif antara variabel e-service quality terhadap keputusan pembelian online. Artinya setiap terjadi kenaikkan nilai 1 dari variabel e-service quality, maka keputusan pembelian online pengguna Tokopedia akan mengalami peningkatan sebesar 0,217.

\section{Uji Hipotesis}

Pengujian hipotesis dalam penelitian ini menggunakan pengujian secara parsial yang terdiri dari uji $t$, pengujian secara simultan yakni dengan uji F. berikut merupakan hasil uji hipotesis menggunakan aplikasi SPSS versi 26.0.

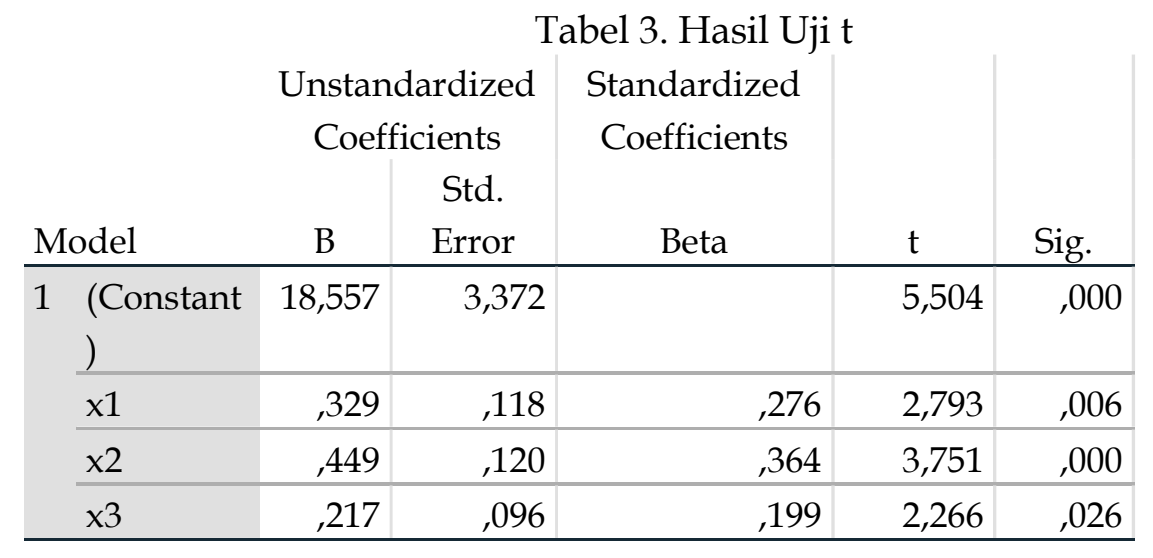

a. Dependent Variable: y1

Berdasarkan tabel 3 dapat dilihat bahwa t-hitung variabel e-trust sebesar 2,793 dengan signifikan probabilitas sebesar 0,000, variabel e-wom memiliki nilai t-hitung sebesar 3,751 dengan signifikasi probabilitas sebesar nol dan variabel e-service quality sebesar 2,266. Berdasarkan nilainilai tersebut, maka dapat disimpulkan bahwa: Hasil perhitungan uji t pada variabel $e$-trust menunjukkan bahwa t-hitung $>\mathrm{t}$-tabel yaitu 18,557 > 1,966 dengan nilai signifikansi $0<0,05$ artinya secara parsial e-trust $(\mathrm{X} 1)$ berpengaruh signifikan terhadap keputusan pembelian online sebesar 27,6\%. Maka dapat disimpulkan bahwa H1 diterima.

Hasil perhitungan uji $\mathrm{t}$ pada variabel $e$-wom menunjukkan bahwa t-hitung $>\mathrm{t}$-tabel yaitu $3,751>1,966$ dengan nilai signifikasi $0<0,05$ artinya secara parsial e-wom (X2) berpengaruh signifikan terhadap keputusan pembelian online sebesar 36,4\%. Maka dapat disimpulkan bahwa $\mathrm{H} 2$ diterima. Hasil perhitungan uji t pada variabel e-service quality menunjukkan bahwa t-hitung $>$ t-tabel yaitu2,266 $>1,966$ dengan nilai signifikasi $0<0,05$ artinya secara parsial e-service quality (X3) berpengaruh signifikan terhadap keputusan pembelian online sebesar 19,9\%. Maka dapat disimpulkan bahwa $\mathrm{H} 3$ diterima.

Sementara itu, berdasarkan tabel 4 dapat dilihat nilai F hasil $(33,937)>\mathrm{F}$ tabel $(2,70)$, dan nilai Sig. $<0,05$, sehingga dapat disimpulkan bahwa $e$-trust, $e$-wom dan e-service quality memiliki pengaruh secara simultan terhadap keputusan pembelian online pada pengguna Tokopedia. Maka dari itu dapat dikatakan $\mathrm{H} 4$ diterima.

Tabel 4. Hasil uji F

\begin{tabular}{|c|c|c|c|c|c|c|}
\hline Model & & Sum of Squares & $\mathrm{df}$ & Mean Square & $\mathrm{F}$ & Sig. \\
\hline 1 & Regression & 766,886 & 3 & 255,629 & 33,937 &, $000^{\mathrm{b}}$ \\
\hline
\end{tabular}




\begin{tabular}{l|r|r|r|r|r}
\hline Residual & 723,114 & 96 & 7,532 & \\
\hline Total & 1490,000 & 99 & & \\
\hline
\end{tabular}

\section{Koefisien Determinasi}

Berdarkan tabel 5, didapat nilai R square sebesar 0,515, sehingga dapat disimpulkan variabel independen yang digunakan pada penelitian kali ini dapat mempengaruhi variabel dependen sebesar $51,5 \%$, dan $48,5 \%$ lainnya dipengaruhi oleh variabel lainnya.

Tabel 5. Hasil Uji Koefisien Determinasi

\begin{tabular}{|c|c|c|c|c|}
\hline \multicolumn{5}{|c|}{ Uji R² } \\
\hline Model & $\mathrm{R}$ & R Square & $\begin{array}{l}\text { Adjusted R } \\
\text { Square }\end{array}$ & $\begin{array}{c}\text { Std. Error of the } \\
\text { Estimate }\end{array}$ \\
\hline 1 & ,717a & ,515 &, 500 & 2,745 \\
\hline
\end{tabular}

\section{PEMBAHASAN}

Pengaruh e-trust terhadap keputusan pembelian online

Berdasarkan hasil pengujian hipotesis dalam penelitian ini, diperoleh bahwa e-trust memiliki pengaruh positif dan signifikan terhadap keputusan pembelian online. Variabel $e$-trust berpengaruh terhadap keputusan pembelian online sebesar 27,6\%. Hal ini didukung dengan hasil analisis deskriptif dimana responden memberikan penilaian yang tinggi pada dimensi ketulusan dan integritas. Responden merasakan bahwa Tokopedia memiliki komitmen dalam menyediakan kebutuhan dan apa yang diinginkan oleh pelanggannya, Tokopedia selalu memberikan produk dan jasa sesuai yang diharapkan oleh pelanggannya.

Hasil penelitian ini sejalan dengan penelitian yang dilakukan Mauludiyahwati (2017) yang menemukan adanya pengaruh positif dan signifikan variabel kepercayaan terhadap keputusan pembelian.

Pengaruh E-wom terhadap keputusan pembelian online

Berdasarkan hasil pengujian hipotesis dalam penelitian ini, diperoleh bahwa e-wom memiliki pengaruh positif dan signifikan terhadap keputusan pembelian online. Variabel e-wom berpengaruh terhadap keputusan pembelian online sebesar 36,4\%. Hal ini didukung dengan hasil analisis deskriptif yang memberikan penilaian di atas rata-rata pada dimensi concern for others dan helping the company. Tokopedia mampu memberikan fasilitas dalam berinteraksi dengan penjual. Hal ini dimaksudkan agar pelanggan dapat memastikan ketersediaan barang yang ingin dibeli dan spesifikasinya.

Hasil penelitian ini sejalan dengan penelitian sebelumnya yang dilakukan oleh Nurrohman (2018) yang menyatakan bahwa electronic word of mouth berhubungan positif dan signifikan terhadap keputusan pembelian.

\section{Pengaruh E-service quality terhadap keputusan pembelian online}

Berdasarkan hasil pengujian hipotesis dalam penelitian ini, diperoleh bahwa e-service quality berpengaruh secara signifikan terhadap keputusan pembelian online. Variabel e-service quality berpengaruh terhadap keputusan pembelian online sebesar 19,9\%. Apabila dikaji dari hasil statistik deskriptif, jawaban responden memberikan penilaian di atas rata-rata pada dimensi fulfillment, system availability dan privacy. Sistem transaksi tokopedia dirasakan mampu dalam memberikan 
aktivitas belanja yang aman dan nyaman bagi pelanggannya, hal ini didasarkan pada distribusi jawaban responden pada item situs Tokopedia selalu menepati janji dalam menjaga aktivitas belanja yang aman dan nyaman. Berbelanja di Tokopedia mememberikan fasilitas yang efisien bagi pelanggannya untuk mencari produk yang diinginkan, dan informasi yang berkaitan pada produk tersebut.

Tokopedia bertanggung jawab penuh atas transaksi yang dilakukan pelanggannya, mulai dari proses verifikasi pembayaran sampai pembatalan transaksi, proses pembatalan dan refund uang yang cepat menjadikan alasan pelanggan tokopedia merasa nyaman berbelanja di Tokopedia. Hasil penelitian ini sejalan dengan penelitian yang dilakukan Fakhrur (2017) yang menemukan bahwa variabel $e$-trust berpengaruh positif terhadap keputusan pembelian online.

Pengaruh e-trust, e-wom, dan e-service quality terhadap keputusan pembelian online

Secara keseluruhan, hasil pengujian hipotesis juga menunjukkan terdapat pengaruh secara simultan e-trust, e-wom, dan e-service quality terhadap keputusan pembelian online pengguna Tokopedia. Hasil penelitian ini sejalan dengan studi yang dilakukan oleh Mauludiyahwati (2017), yang menyatakan bahwa kepercayaan, keamanan, kualitas pelayanan dan persepsi risiko secara simultan berpengaruh positif terhadap keputusan pembelian. Hasil tersebut secara deskriptif diperkuat dengan adanya penilaian di atas rata-rata pada variabel $e$-trust, yakni item "memenuhi kebutuhan", lalu pada variabel $e$-wom, pada item mengenai "meningkatkan produk", kemudian pada variabel e-service quality, pada item "bertanggung jawab", dan pada variabel keputusan pembelian, pada item mengenai "banyak pilihan toko".

Variabel e-wom pada penelitian ini memiliki pengaruh yang paling tinggi, diikuti dengan variabel e-trust. Sedangkan e-service quality, memiliki pengaruh terendah terhadap keputusan pembelian online pada pengguna Tokopedia di Bandar Lampung. Pada variabel $e$-wom, dimensi concern for others dan helping the company mendapatkan penilaian di atas rata-rata. Hal tersebut membuktikan bahwa Tokopedia mampu memberikan fasilitas yang baik bagi konsumen dalam berinteraksi dengan penjual. Hasil penelitian ini sejalan dengan Sernovitz (2009:19), bahwa e-wom atau komunikasi yang baik akan mempengaruhi keputusan pembelian online.

Walaupun demikian, pada penelitian ini variabel e-service quality memiliki pengaruh yang sangat kecil $(19,9 \%)$, maka dari itu Tokopedia diharapkan untuk dapat menambahkan fitur rekomendasi kepada para pengguna aplikasi, tentang barang-barang ataupun toko yang trend pencariannya sedang tinggi untuk mempermudah pengguna mencari produk yang dibutuhkan, menyaring komentar ulasan yang tidak sesuai dalam aplikasi, serta sortasi kualitas produk atau toko berdasarkan evaluasi ulasan konsumen.

Secara keseluruhan, berdasarkan hasil penelitian, responden memberikan penilaian tinggi untuk memutuskan bertransaksi online melalui Tokopedia. Responden percaya bahwa Tokopedia mampu memberikan pelayanan yang baik, karena Tokopedia dapat memberikan jasa untuk memenuhi kebutuhan konsumennya. Terdapat juga banyak pilihan toko, sehingga konsumen dapat leluasa memilih produk yang diinginkan. Selain itu, Tokopedia juga bertanggung jawab dalam memberikan keamanan dalam bertransaksi online.

\section{KESIMPULAN}

Secara teoritis, penelitian ini membuktikan bahwa keputusan pembelian online berhubungan dengan perilaku konsumen. Konsumen yang mengerti dan paham terhadap keandalan suatu produk untuk memenuhi kebutuhannya, dan ditunjang dengan kualitas layanan serta promosi sebagai stimulus pemasaran, bercampur dalam kotak hitam pembeli, sehingga mempengaruhi keputusan pembelian mereka. Dengan demikian, terdapat keterkaitan marketing stimuli, black box, dan target audience respon (Sopiah \& Sangaji, 2013:13).

Besarnya pengaruh variabel e-wom terhadap keputusan pembelian, menunjukkan 
pentingnya ulasan (review) konsumen dalam menentukan keputusan pembelian melalui online. Perlu dukungan peningkatan pada aspek kemampuan Tokopedia dalam memberikan kepercayaan (ability), kemudahan dalam membagikan pengalaman berbelanjanya menggunakan aplikasi Tokopedia (expressive positive feeling), dan (efficiency) dalam memenuhi kebutuhan pelanggan.

Keterbatasan penelitian ini mengkaji e-trust, e-wom, dan e-service quality terhadap keputusan pembelian online. Sehingga ke depan perlu dilakukan pengembangan lebih lanjut dengan menambahkan variabel pengalaman berbelanja atau kemudahan sistem belanja online, sehingga untuk peneliti selanjutnya dapat memahami keputusan pembelian berbelanja online secara komprehensif.

\section{DAFTAR PUSTAKA}

Amalia, D. 2019. Pengaruh big-five personality, konformitas, dan faktor demografi terhadap perilaku pembelian impulsif dalam berbelanja online pada wanita. Thesis. Fakultas Psikologi UIN Syarif Hidayatullah Jakarta.

Ansyah, F., \& Abror, A. (2019). Pengaruh persepsi risiko dan kepercayaan pada vendor terhadap minat beli yang dimediasi oleh sikap konsumen toko online Lazada di Kota Padang. Jurnal Kajian Manajemen dan Wirausaha, 1(1), 46-58.

Chase, R. B., Jacobs, R. F., \& Aquilano, N. J. (2006). Operations management for competitive advantage. 11th edition. Singapore: MC. Graw Hill Companies.

Evandio, A. (2021). Tokopedia nikmati berkah imlek, ini penjualan yang melejit. Bisnis.com. 20 Februari 2021. Diakses dari m.bisnis.com/amp/read/20210220/266/1358723/tokopedia-nikmati-berkah-imlek-inipenjualan-yang-melejit.

Tjiptono, F. (2014). Strategi pemasaran. Edisi 4. Yogyakarta: Penerbit Andi.

Tjiptono, F. (2014). Pemasaran jasa: Prinsip, penerapan, dan penelitian. Yogyakarta: Penerbit Andi.

Rozi, I. F. (2017). Pengaruh e-service quality terhadap keputusan pembelian tiket kereta api online (Konsumen pembeli tiket kereta api online PT.KAI DAOP 8 Surabaya Gubeng). Jurnal Pendidikan Tata Niaga, 1(1), 118-122.

Jayani, D. H., \& Fitra, S. (2019). 10 e-commerce dengan pengunjung terbesar kuartal III-2019. $\begin{array}{lllll}\text { Databoks.katadata.co.id. } & 22 & \text { Oktober } & 2019 . & \text { Diakses }\end{array}$ https://databoks.katadata.co.id/datapublish/2019/10/22/inilah-10-e-commerce-denganpengunjung-terbesar.

Kotler, P. \& Amstrong, G. (2012). Prinsip-prinsip Pemasaran. Edisi 13. Jilid 1. Jakarta: Erlangga.

Mahkota, A. P., Suyadi, I., \& Riyadi. (2014). Pengaruh kepercayaan dan kenyamanan terhadap keputusan pembelian. Jurnal Administrasi Bisnis, 8(2), 1-7.

McLeod, R. \& Schell, G. P. (2004). Management information systems. 9th Ed. New Jersey: Pearson Education Inc.

Paludi, S. (2016). Analisis pengaruh electronic word of mouth (E-wom) terhadap citra destinasi, kepuasan wisatawan, dan loyalitas destinasi Perkampungan Budaya Betawi (PBB) Setu Babakan Jakarta Selatan. Tesis. MM IBN Jakarta.

Pavlou, P.A. (2003). Consumer acceptance of electronic commerce: Intergrating trust and risk with the technology acceptance model. International Journal of Management Reviews, 7(3), 101-134.

Purwana, D., Rahmi, R., \& Aditya, S. (2017). Pemanfaatan digital marketing bagi usaha mikro, kecil, dan menengah (UMKM) di Kelurahan Malaka Sari, Duren Sawit. Jurnal Pemberdayaan Masyarakat dan Madani, 1(1). DOI: https://doi.org/10.21009/JPMM.001.1.01.

Siagian, H., \& Cahyono, E. (2014). Analisis website quality, trust, dan loyalty pelanggan online shop. Jurnal Manajemen Pemasaran, 8(2), 55-61.

Schiffman, L. O., \& Kanuk, L. L. (2010). Perilaku konsumen. (Zulkifli Kasip, Alih Bahasa). Jakarta: PT. Indeks.

Mauludiyahwati, S. (2017). Pengaruh kepercayaan, keamanan, kualitas pelayanan dan persepsi risiko menggunakan e-commerce terhadap keputusan pembelian online (Survei pada konsumen www.lazada.co.id). Skripsi. Universitas Negeri Yogyakarta. 
Sernovitz, A. (2009). Word Of mouth marketing: How smart companies get people talking. New York: Kaplan Publishing.

Varmaat, S. C. (2007). Discovering computers: Menjelajah dunia komputer fundamental. Edisi 3. Jakarta: Salemba Infotek.

Yunitasari, F. (2018). Pengaruh dimensi electronic word of mouth (E-wom) terhadap keputusan pembelian di marketplace dalam perspektif ekonomi islam (Studi pada mahasiswa fakultas ekonomi dan bisnis islam angkatan 2015). Undergraduate Thesis. UIN Raden Intan Lampung.

Setyowati, D., \& Suryoko, S. (2020). Pengaruh e-service quality terhadap keputusan pembelian melalui $e$ trust sebagai variabel mediasi (Studi pada pengguna situs BukaLapak di Kota Semarang). Jurnal Ilmu Administrasi Bisnis, 10(1), 251-260.

Kartika, M., \& Ganarsih, R. L. (2018). Analisis e-wom, online shopping experience dan trust terhadap keputusan pembelian konsumen e-commerce shopee pada mahasiswa pascasarjana Universitas Riau. Jurnal Tepak Manajemen Bisnis, 11(2), 289-307.

Nugraha, R. D., Siburian, P. S., \& ZA, S. Z. (2019). Pengaruh trust, ease of use dan information quality terhadap keputusan pembelian secara online pada social media instagram di samarinda. Jurnal Ilmu Manajemen Mulawarman (JIMM), 3(1).

Oktaviani, F. A. (2020). Pengaruh persepsi harga, diskon, dan e-wom terhadap keputusan pembelian voucher traveloka eats. Doctoral Dissertation. Universitas Bakrie Jakarta.

Perera, C., Nayak, R., \& Long, N. (2019). The impact of electronic-word-of-mouth on e-loyalty and consumers e-purchase decision making process: A social media perspective. International Journal of Trade, Economics and Finance, 10(4), 86-91.

Tjhin, V. U., \& Aini, S. R. N. (2019, May). Effect of e-wom and social media usage on purchase decision in clothing industry. In Proceedings of the 2019 5th International Conference on E-business and Mobile Commerce, (pp. 30-34).

Gupron, G. (2020). Analisis kepuasan konsumen melalui e-service quality terhadap keputusan pembelian daring di aplikasi bukalapak.com. (Studi pada mahasiswa Universitas Batanghari Jambi). Jurnal Manajemen Pendidikan dan Ilmu Sosial, 1(1), 337-348.

Oktari, S. (2018). Pengaruh kepercayaan, e-service quality, dan kualitas website terhadap keputusan pembelian di lazada pada mahasiswa fakultas ilmu sosial dan politik Universitas Sumatera Utara. Skripsi. Fakultas Ekonomi dan Bisnis, Universitas Sumatera Utara, Medan.

Amanah, D., Harahap, D. A., \& Lisnawati, D. (2017). Exploring online purchase decision among university students in Indonesia. Journal of Humanities and Social Science, 22(5), 72-77.

Mahfud, A. G., \& Soltes, V. (2016). Effect of e-service quality on consumer interest buying (Case study on the website Korean denim). IOSR Journal of Economics and Finance, 07(04), 61-67.

Sindunata, I., \& Wahyudi, B. A. (2018). Pengaruh e-wom (Electronic-word-of-mouth) terhadap keputusan pembelian di agoda. com. Jurnal Hospitality dan Manajemen Jasa, 6(1), 128-138.

Kalia, P. (2016). E-service quality, consumer satisfaction and future purchase intentions in e-retail. E-Service Journal, 10(1), 24-41. 